\title{
SUSTAINABLE DEVELOPMENT OF UKRAINIAN IRON AND STEEL INDUSTRY ENTERPRISES IN REGARDS TO THE BULK MANUFACTURING WASTE RECYCLING EFFICIENCY IMPROVEMENT
}

\author{
O. Filonenko ${ }^{1 *}$ \\ ${ }^{I}$ Metinvest Holding, Mariupol, Ukraine \\ *Corresponding author: e-mail aleksandr.filonenko@metinvestholding.com, tel.+380675445551
}

\begin{abstract}
Purpose. Identify the tendency of sustainable development of Ukrainian iron and steel industry enterprises regarding the raising of the bulk manufacturing waste recycling efficiency.

Methods. To achieve this purpose, a comprehensive methodological approach has been used, including an analysis of Ukrainian and foreign statistics data on the bulk manufacturing waste accumulation and handling, the analysis of potential consumers of goods from the Mining and Metallurgical Company (MMC) waste products of Ukraine, as well as the study of common policy tools for settling the issues of manufacturing waste accumulation in world practice.

Findings. It was determined that smelter slags, which are an underestimated resource in the Ukrainian economy, are of primary interest in terms of the efficiency of bulk manufacturing waste recycling in Ukraine. In international practice, ferrous slags are used as a valuable resource base for many areas of business, which in most cases became possible through the implementation of favorable policies in the area of resource-saving and ecology. In addition, this paper identifies the main market barriers hampering the smelter slags recycling in Ukraine, as well as additional market restrictions for Mariupol metallurgical complexes that arose as a result of a military conflict.

Originality. A number of policy tools (favorable policies in the area of resource-saving and ecology) have been formulated at national and regional levels to create the necessary competitive conditions for the smelter slags recycling and to support the sustainable development of MMC enterprises of Ukraine.

Practical implications. The introduction of the proposed control mechanisms for the ferrous slags recycling will enable the provision of such industries as road engineering, cement and concrete industry, agriculture and a number of other industries with valuable industrial raw materials and above all, to ensure a balance of sustainability at the local level and eliminate the need for new territories to be allocated for manufacturing waste.
\end{abstract}

Keywords: sustainable development, bulk manufacturing waste, smelter slag, waste recycling, policy tools

\section{INTRODUCTION}

The industrial and economic activity of manufacturing enterprises is inevitably linked with the waste production. But it is the specific subsequent waste handling that determines how far the business practice conforms to the principles of sustainable development. The ratio of waste recycling volume to the volume of their production, i.e. the proportion of the return of waste in the production cycle or the waste application in other areas of business, can be taken as a sustainable indicator of industrial and economic activity. This indicator gives an overview of waste handling culture, without taking into account sector specifics, environmental policies and other aspects (Lundin, Olofsson, Pettersson, \& Zetterlund, 2004; Bondarenko, Kovalevska, \& Dychkovskyi, 2010).
Of course, the existing environmental policy is played the key role in ensuring sustainable industrial and economic activity in the field of waste handling, which establishes rules and determines the procedure for contradictions resolving arising in relations between the subjects of economic activity, the state and society. Enterprises cannot infinitely accumulate waste, since this will lead to a disturbance in the balance of sustainability due to the growing negative impact on the environment, which will be followed by deterioration of local social conditions. However, economic entities must have technical capabilities and economic incentives for recycling waste or transferring them to other sectors of the economy, since otherwise the balance of stability will also be violated due to the decrease of their competitiveness, which will be followed by deterioration of local social conditions. 


\section{BULK WASTE PRODUCTION AND HANDLING IN THE ECONOMY OF UKRAINE}

The main sources of bulk waste production in the Ukrainian economy for 2016 are the enterprises of the mining and metallurgical companies (Table 1). The mining industry accounted for $75.2 \%$ of the gross volume of waste production in the Ukrainian economy, mainly due to the activity of enterprises producing metallic ores. The second largest volume of waste production is the refining industry, whose share in the gross volume of waste production in the Ukrainian economy amounted to $18.6 \%$, mainly due to the activity of metallurgical enterprises.

Table 1. Waste production and handling in the main economic sectors of Ukraine for 2016 (Okruzhayushchaya sreda..., 2017)

\begin{tabular}{|c|c|c|c|}
\hline Main economic sectors, where bulk waste is produced & $\begin{array}{c}\text { Produced waste, } \\
\text { thousand tones }\end{array}$ & $\begin{array}{c}\text { Main economic } \\
\text { sectors, where bulk } \\
\text { waste is produced }\end{array}$ & $\begin{array}{c}\text { Produced waste, } \\
\text { thousand tones }\end{array}$ \\
\hline All economic sectors of Ukraine & 289523.6 & 84630.3 & 157379.3 \\
\hline Mining industry & 217907.8 & 55016.0 & 136396.2 \\
\hline - coal mining & 10495.8 & 1198.2 & 8073.2 \\
\hline - metallic ore extraction & 202923.0 & 51457.4 & 127504.2 \\
\hline - extraction of other mineral resources and quarry mining & 4378.1 & 2353.0 & 740.1 \\
\hline Refining industry & 53857.9 & 22088.7 & 10168.1 \\
\hline - coke and refined products production & 2434.9 & 2131.7 & 723.2 \\
\hline - metallurgical production & 42029.3 & 16939.9 & 8676.4 \\
\hline - other non-metallic mineral products production & 1041.7 & 1894.1 & 38.8 \\
\hline - chemical products production & 840.0 & 81.7 & 237.9 \\
\hline - food products production & 5089.8 & 588.3 & 12.3 \\
\hline Agriculture, forestry and fishing & 8715.5 & 6203.5 & 75.5 \\
\hline Power engineering & 7511.5 & 388.3 & 3884.0 \\
\hline
\end{tabular}

Thus, in 2016, the largest amount of waste was produced and accumulated by enterprises producing metallic ores (202.9 million tons and 127.5 million tons, respectively). Bulk waste from enterprises producing metallic ores is a stripping, barren rock that accompanies ore minerals, and waste of metallic ores, which at this stage of development do not represent the resource value for further recycling. The volume of accumulated waste by the enterprises, producing metallic ores, amounted to $93.5 \%$ in all mining industry. These types of waste, in the world-wide practice, are used partly for mining earth backing and the mined-land reclamation that are damaged by mining operations. In other spheres of the economy, the mining industry's waste practically has no valuable resource.

Metallurgical enterprises were the second in production and accumulation of wastes in 2016 (42.0 million tons and 8.7 million tons, respectively). The volume of waste accumulation from metallurgical enterprises amounted to $85.3 \%$ of the total accumulated waste volume in the entire refining industry.

\section{IRON AND STEEL INDUSTRY WASTE}

The bulk manufacturing waste of iron and steel industry (about $80 \%$ ) is made up of smelter slag, of which about two-thirds are blast-furnace slags extraction, which are associated with the ferrous metal production, and one third are steel-smelting slags extraction that are associated with various steel grade production (Geiseler, 1996).

The EUROSLAG European Association of Producers and Consumers of smelter slags has identified the classification of smelter slags (Fig. 1). This classification is applicable to the iron and steel industry of Ukraine for steelmaking slag types alteration. At some iron and steel enterprises of Ukraine up to now, open-hearth furnaces (OHF), which produce open hearth steel and, accordingly, open-hearth slag, are used.

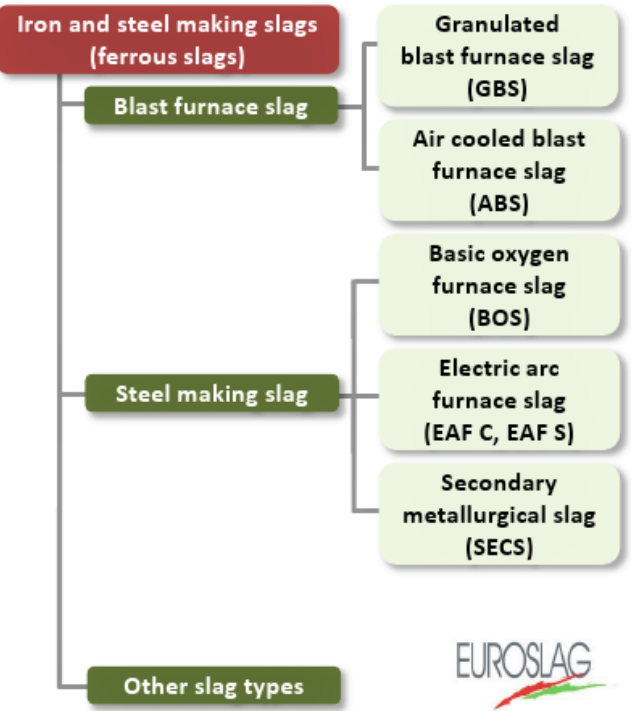

Figure 1. Classification of smelter slags (Euroslag, 2018)

In the iron and steel industry of the EU countries, like in the vast majority of other countries, steel producers refused to use the open-hearth method of production, mainly because of its high energy intensity.

Other iron and steel industrial wastes (about 20\% of the total mass) are wash water of wet gas purification and dust collected by dry gas-cleaning installations. But unlike the main volume of slags, dust and gas treatment residue, as a rule, are subjected to recycling, i.e. return to the production cycle as additives to burden material s of agglomeration and blast-furnace and steel-smelting extraction. The recycling volume of smelter slags is substantially limited, since slags according to their physical and chemical properties are more likely to mineral raw materials (Lundin, Olofsson, Pettersson, \& Zetterlund, 2004; Kuz'menko, Petlyovanyy, \& Stupnik, 2013; Cheremisina \& Schenk, 2017). 


\section{HANDLING WITH WASTE RECOVERABILITY IN IRON AND STEEL INDUSTRY}

The largest interest in terms of bulk manufacturing waste recycling is smelter slag. Unlike bulk waste in the mining industry, ferrous slags are resource base for some sectors of the economy. Successful international practice of smelter slags recycling in road engineering, cement industry, concrete industry, agricultural sector and a number of other economy sectors, as well as the regulatory documentation in force in Ukraine, confirm the high economic value of smelter slags.

\subsection{World experience}

In the newsletter of the World Association of Steel Manufacturers, which deals with coproducts of iron and steel industry, the following data is given: "The global

(a)

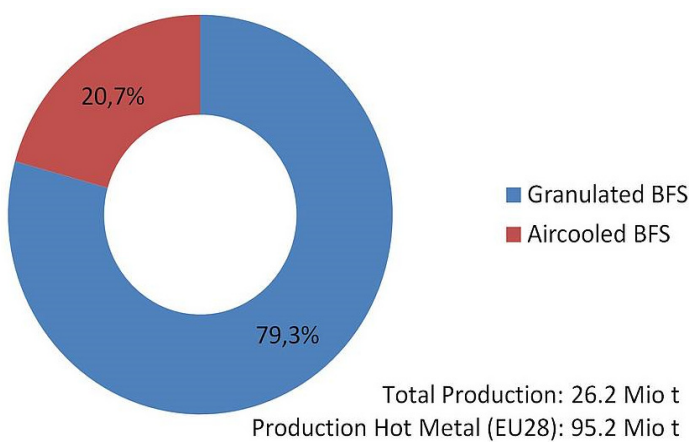

(c)

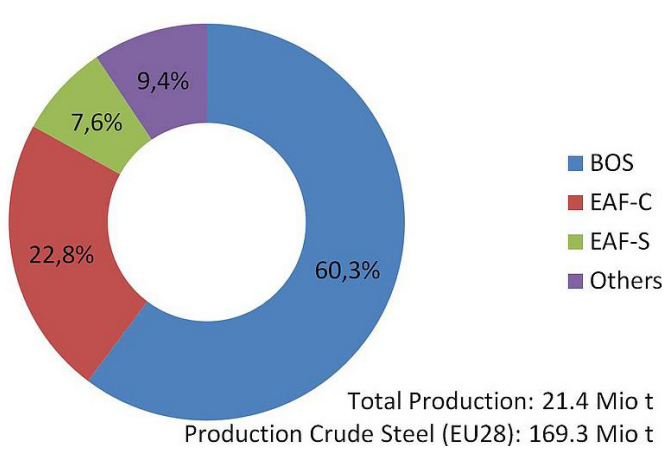

level of smelter slag recycling is from $80 \%$ for steelsmelting slag and, practically, up to $100 \%$ for blast furnace slags. Environmental and economic benefits suggest that there is a huge potential for slag utilization increasing in many countries" (Fact Sheet..., 2016).

In the world practice, waste, representing a waste recoverability for metallurgy, returns to the production cycle, and waste with high minerals content are transmitted as raw materials to other industries under market conditions, but more often for purposes of current greening of economy policy or target state programs of interindustry interaction.

Figure 2 provides infographics for smelter slag production and utilization in EU countries, borrowed from the European Association of Producers and Consumers of EUROSLAG of smelter slags.

(b)

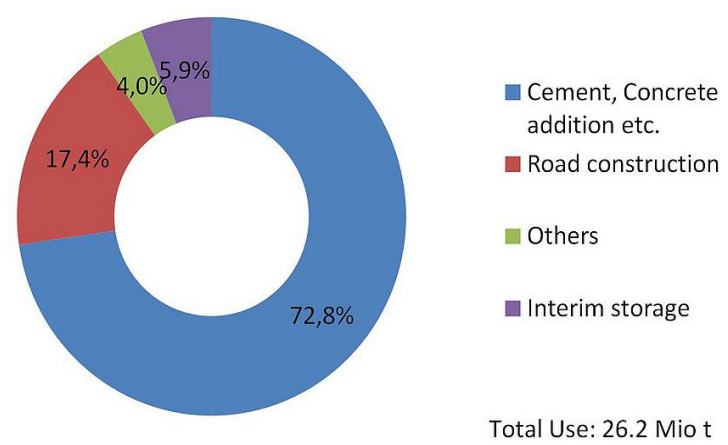

(d)

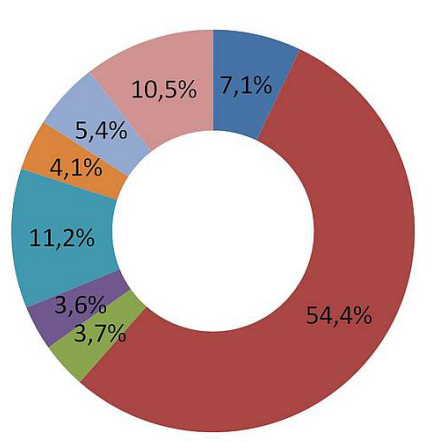
addition etc. - Road construction - Hydraulic Eng. Fertilizer Metallurgical use Others

Interim storage - Final deposit Total Use: 21.8 Mio t
- Cement, Concrete

Figure 2. Statistics on the smelter slags production and utilization in the EU countries in 2014: (a) production of Blast Furnace Slag (BFS); (b) use of BFS; (c) production of Steel Making Slag (SMS); (d) use of SMS

According to the association EUROSLAG data, in 2014, 1.55 million tons of blast-furnace slags and 1.17 million tons of steelmaking slag were allocated in temporary storage of iron and steel enterprises of the EU countries, while 2.29 million tons of steelmaking slags were allocated in iron and steel enterprise piles. Thus, only $5.7 \%$ of the gross smelter slags volumes (47.6 million tons) were in temporary storage, and $4.8 \%$ were placed in piles.

The high percentage of slag recycling in the EU iron and steel industry is mainly due to favorable policies in the field of resource-saving and ecology (Geiseler, 1996).

\subsection{Ukrainian experience}

The current level of smelter slags recycling in Ukraine is significantly lower than the general level. This indicates that, firstly, this industry-related resource is underestimated by the Ukrainian economy, secondly, the environmental policy in the field of waste handling requires reformation, since enterprises are forced to accumulate slags in piles, and, thirdly, interdisciplinary in the issues of smelter slags recycling are often limited to forprofit efficiency, which reduces the priority of resource conservation and ecology (Onyshchenko, Bryzhan, \& Chevhanova, 2014; Kravtsiv \& Kolodiichuk, 2016).

The practical level of smelter slags recycling in the countries of the former USSR, including Ukraine, is on 
average $20 \%$ of their production volume (Krasnyanskiy, 2007). According to experts, now Ukrainian iron and steel enterprises have accumulated more than 300 million tons of smelter slags in the piles, and the annual increase in the slag accumulation can amount to 10 million tons at normal production capacity loading of enterprises.

At some iron and steel enterprises of Ukraine is to apply steel-smelting slags recycling, from which extracted iron-bearing scrap and fluxing materials and returned to the production cycle (Gromova, 2012). Steel-smelting slag recycling in other spheres of economic is small. Thus, more than $70 \%$ of the steel-smelting slags volume is located in piles or temporary slag production storage of enterprises (Kuznetsov, Protopopov, Feiler, \& Temlyantsev, 2017; Perepelitsyn, Merzlyakov, Kochetkov, Yagovtsev, \& Panov, 2017).

Blast-furnace slags virtually do not return to the metallurgical cycle due to low (up to $1 \%$ ) iron content. As a rule, they are granulated at water-stream granulation interlockings, and basket screenings, after ebullition cooling, are taken to disposal sites. Traditionally, blastfurnace granulated slag in Ukraine is in demand in the cement and construction industrial enterprises, but for a number of reasons it is not fully realized. In addition, existing Ukrainian blast-furnace slag granulation technologies are far from good practice that does not allow providing high quality to granulated slag by vitrified indicator (average indicator in Ukraine $-50 \%$, in the world - more than 90\%). For products from blast-furnace slags piles, demand is often limited to the needs of the regional road engineering market. Therefore, it is not always economically feasible to organize the production of fractionated broken slag from the blast-furnace slag stocker without the guarantee of its merchandising or the target utilization program, since production will lead not only to economic losses, but also to the overflow of stores with slag products, which will require new areas.

Taking into account the obvious lag upon stability indications of the production and commercial activities from world practice in the issues of smelter slags recycling, it is necessary, first of all, to make changes in the waste management policy and to develop target utilization program of some waste products types, which have a resource value for the economy.

A lot of countries, having encountered the environmental consequences and extent of waste accumulation, have introduced favorable policies and sectoral programs in the field of subsoil conservation, resource-saving and ecology. This allowed for a relatively short period of time to stop the growth of waste accumulation, to loading-out piles and to have a positive economic effect from the industrial waste recycling (Marín-Guirao, Atucha, Barba, López, \& Fernández, 2005; Elshkaki, 2013). In the Ukrainian economy, iron and steel industry is the basic industry and will continue to keep its position in the domestic and world steel markets; therefore its sustainable growth and long-term competitiveness are quite relevant. Sustainable growth is not possible without setting environmental goals, the most important aspect of which is the culture of waste handling. The result of sustainable economic activity should be to ensure the full smelter slag piles loading-out and to utilize the current volumes of their production. Thus, the high-priority task for further sustainable iron and steel industry growth is to ensure slags recycling in the amount of their production. Execution of this task will stop the smelter slags accumulation growth in piles. And, accordingly, the secondary task is to ensure the comprehensive slags utilization of the current slag yield with gradual waste piles accumulations utilization. Execution of this task will allow not only to ensure slags recycling of the current yield, but also to eliminate the slag piles in the foreseeable future. Backbone industry orientation on the sustainable growth policy requires the expansion of inter-sectoral interaction, which, in turn, should lead to changes in the current environmental policy.

\section{FEATURES OF THE PRYAZOVIA IRON AND STEEL ENTERPRISES DEVELOPMENT}

To date, for Mariupol metallurgical complexes, MMC named by Illich, and Azovstal, there is a unique situation with access to the markets for slag products merchandising in comparison with other sectorial enterprises. Since the beginning of the military conflict in Donbas, access to the traditional markets for slag products merchandising from Mariupol iron and steel enterprises has undergone additional significant restrictions.

Firstly, two cement plants closest to Mariupol dropped out of the cement industry of Ukraine: Amvrosiivskyi cement plant, which remained on uncontrolled territory, and Kramatorskyi cement plant "Pushka", which closed down in 2015. The nearest operational cement plants are located more than $400 \mathrm{~km}$ from Mariupol in Mykolaiv, Kamianske and Kryvyi Rih (Ukrtsement, 2018). In the nearest region of Pryazovia: Donetsk, Zaporizhzhia and Kherson regions, there are no cement plants (Fig. 3).

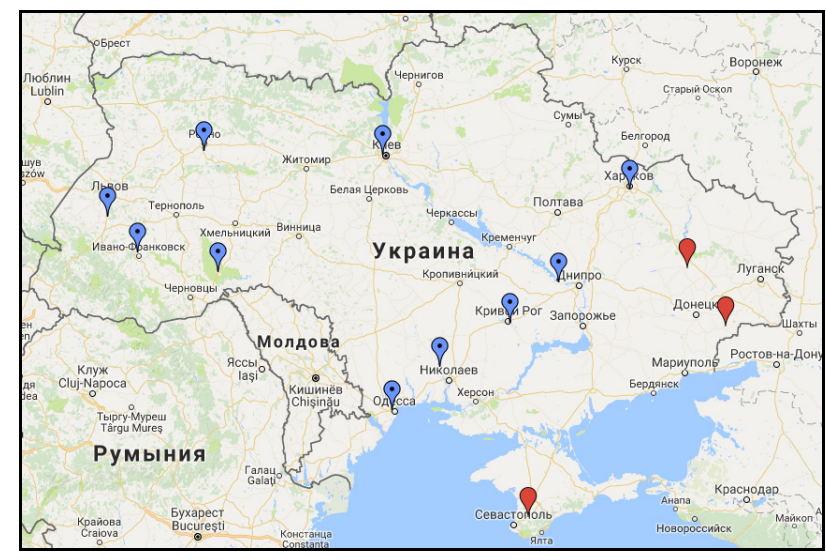

Figure 3. Location of cement manufacturing enterprise in Ukraine (Ukrtsement, 2018)

Secondly, the main road junctions of Donetsk railway remained on uncontrolled territory, which resulted in a decrease in the transportation capacity of industrial goods between Mariupol and other regional centers of Ukraine (Karta zheleznykh dorog..., 2018). Deterioration of transport and logistic connections had a negative impact on the work of Mariupol metallurgical complexes, which periodically experienced supply problems of raw materials, which leads to forced production loss (Fig. 4). 


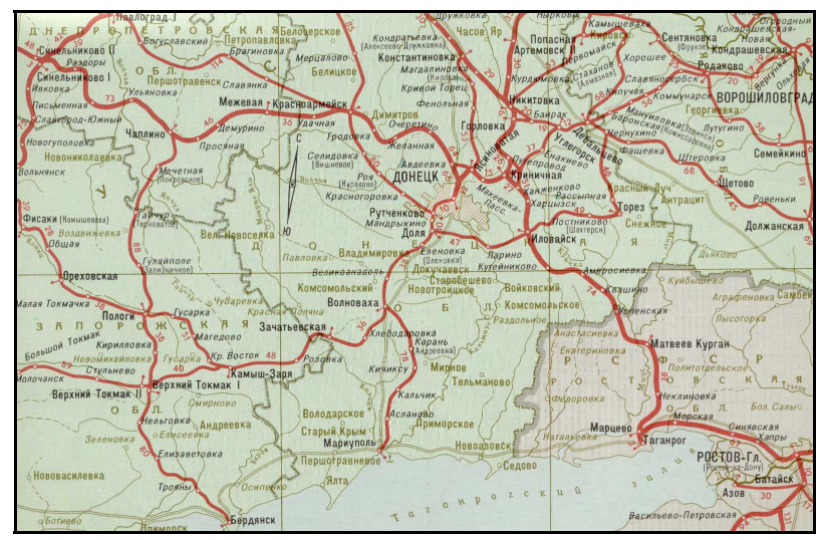

Figure 4. Map of Donetsk and Luhansk regions railways (Karta zheleznykh dorog..., 2018)

In addition, during the last several years the volume of the wagon fleet of Traffic Logistics Center of the State Enterprise "Ukrzaliznytsia" has significantly decreased, which has created a shortage of wagons in almost all economy sectors of Ukraine (Bystritskaya, 2016). But the most acute shortage of wagon fleet to this day is felt by Mariupol iron and steel enterprises.

Thirdly, repair and maintenance highways work near Mariupol, in the Azov region and in the area close to the delineation line were carried out in a very limited volume for several years. Deliveries of broken slag from the Mariupol metallurgical complexes are difficult because the main Ukravtodor working area on current and permanent highways repair is concentrated in the western and central parts of Ukraine, as evidenced by an interactive road map of the MOINF of Ukraine (Derzhavne ahentstvo..., 2018) (Fig. 5).

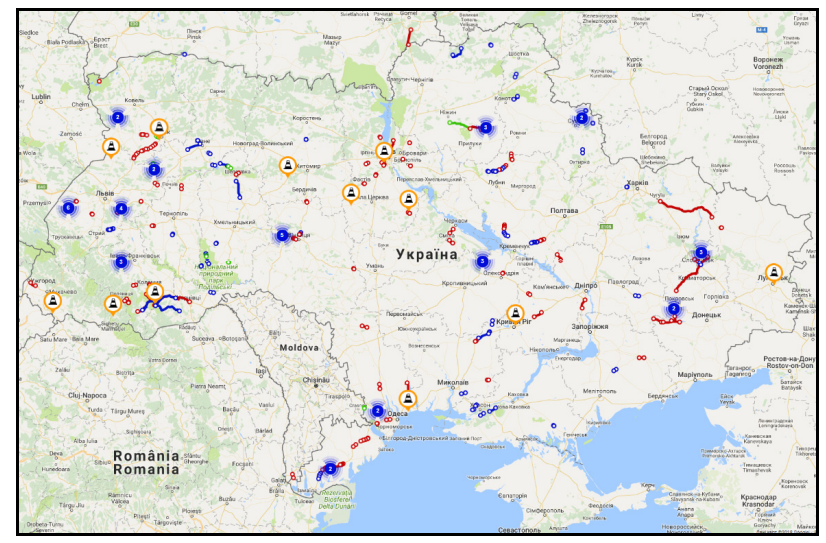

Figure 5. Interactive repair and maintenance highways map (Derzhavne ahentstvo..., 2018)

The isolated location from the target consumers, high transportation tariffs, the limited transportation capacity, the shortage of wagon fleet, the absence of large local and regional infrastructure projects, as well as the absence of a favorable policies in resource-saving and ecology, make the slag production of the Mariupol metallurgical complexes less competitive in comparison with natural raw materials or slag products of other iron and steel enterprises of Ukraine, which are located closer to the consumers. In addition, from 2014, there is no access to potential slag merchandising markets at the regions close to the eastern border of Donetsk region, Russian Federation region and in the Crimea.

Stimulating slag production merchandising volumes by dumping (lowering the selling prices on the slag products of the Mariupol metallurgical complexes) will not pan out, as the transport costs are many times higher than the selling prices for the most slag products. An increase in the tax on the slags allocation in piles will also not lead to the desirable result, since this will not affect the market conditions of the slag products consumption. Thus, the only possible way of settling the slag issue, in particular for the Mariupol metallurgical complexes, is in the field of environmental policy, which is confirmed by a number of examples from the world practice.

\section{BULK MANUFACTURING WASTE RECYCLING IN THE WORLD PRACTICE}

Below there are some examples of favorable policies in bulk manufacturing waste recycling:

In Japan: in 2001, the Law "On Implementation of the Green Procurement Policy" was adopted, according to which state and municipal institutions were obliged to procure according to the target list of goods and services, which included ferrous slags. Already in $2007,70 \%$ of the slag of the iron and steel industry in Japan was procured and utilized internally within the green procurement legislation (Zhu, Geng, Fujita, \& Hashimoto, 2010; Nippon Slag Association, 2018).

In India: during the period of $1999-2008$ the policy of ash-slags recycling of coal-fired thermal power plants was gradually introduced. Since 2009, the Ministry of Ecology and Forestry in India has finally adopted the decree on obligatory application of ash-slags of coalfired thermal power plants in all infrastructure projects, including the construction of roads and overpasses, as well as the remediation of land within a radius of $100 \mathrm{~km}$ from the thermal power station. The decree included the necessity of back ash-slag filling underground and open minings, located within a radius of $50 \mathrm{~km}$ from the thermal power station. As a result, the volume of ash-slags recycling in India grew from $11.6 \%$ in 1999 to $61.37 \%$ in 2012 (Syiemlieh, 2015; Tripathi, Mishra, Dubey, Tripathi, \& Baredar, 2016).

In EU countries: in 2008 The European Commission presented a framework document on green public procurement, which recommended green procurement criteria for the inclusion of environmental issues in the expenditure items of government agencies in the European Union (Communication from the Commission..., 2008). In 2016, the third edition of the "Green Procurement" manual was issued (Buying Green, 2016). The implementation of green procurement policies in each EU states member takes place individually and is currently at different stages of implementation. The criteria and approaches of green procurement policy are the same for all European countries, and existing regulatory instruments may have individual differences. The implementation of the green procurement policy for the EU is voluntary, but following the common approaches and criteria according to green procurement, the European Commission is monitoring regularly. 


\section{RECOMMENDED POLICY TOOLS FOR INCREASING EFFECTIVENESS OF SMELTER SLAGS RECYCLING IN UKRAINE}

The policy tools that can be effective in developing the market for smelter slags recycling for Ukrainian iron and steel enterprises are as follows.

Potential policy tools of the national level:

- legislative confirmation of the smelter slags status as technogenic materials of a special purpose with the formulation of a list of obligative areas of their application;

- to develop cross-sectoral programs for smelter slags recycling with setting target utilization volumes in various spheres of the Ukrainian economy, as well as to make related amendments to legislative acts and technical standard documents in all spheres of slag products application;

- the government decree to establish rules and instructions for slag products purchases by public and private enterprises;

- establish distribution rules of the Road Fund of Ukraine in the Law "On sources of the road economy financing of Ukraine" and the Budget Code of Ukraine, taking into account the target smelter slags volume recycling by local and regional road vehicles;

- to introduce an excise tax on natural materials extraction for road construction with the accumulation of funds on a special account of the Road Fund in order to maintain the priority directions of by-products utilization.

Potential policy tools of the geography level (for Mariupol metallurgical complexes):

- establish additional restrictions on natural materials implementation in road and infrastructure construction in Donetsk and Zaporizhzhia regions, and to determine the target smelter slags volume recycling (i.e. higher than in other regions of Ukraine);

- to create local and regional stores for broken slags storage with placement within a radius of $200 \mathrm{~km}$ from the plant in the main directions of the planned road works;

- create special regional programs for the Donetsk and Zaporizhzhia regions in order to construct road parts with cement-concrete road toppings on the basis of slag products from Mariupol metallurgical complexes.

With the impossibility of implementing regulatory mechanisms facilitating the smelter slags utilization, there will be a need to allocate additional areas from the land fund to create new disposal sites.

\section{CONCLUSIONS}

In Ukraine, the largest manufacturing waste volume is formed in the mining and refining industry, which will remain the basic economy branches in the long-term prospect. A sustainable growth in long-term competitiveness is considered to be a dominant factor in world practice, one of the most important aspects of which is the culture of waste handling. Sustainable growth necessarily involves the environmental goals achievement, and therefore cannot be ensured only within the production and commercial activities, the purpose of which is to maximize profits.

The greatest interest in terms of bulk manufacturing waste recycling is ferrous slags. This industrial resource remains underestimated, and the level of smelter slags utilization in Ukraine is lower than in many other industrial countries, where are target state programs for certain types of manufacturing waste utilization and sectorial favorable policies in resource-saving and ecology spheres.

In this paper, examples of some favorable policies of manufacturing waste recycling from international practice are given. A number of policy tools of the national and regional levels are in place to create the necessary conditions for the sustainable development of the iron and steel enterprises of Ukraine in terms of utilization of such bulk manufacturing waste as slag, including overcoming the additional market restrictions encountered by Mariupol metallurgical complexes since the beginning of the military conflict in Donbas.

\section{ACKNOWLEDGEMENTS}

The work was carried out within the thematic approach of the government program "State Program Concept of Waste Handling for 2013 - 2020", as well as within the research work "Scientific substantiation of the methodological, technological, ecological and legal basis of useful components extraction from technogenic deposit of Ukraine" (No. of State Registration 0116U004619). The author expresses his gratitude to the management of PJSC "Illich MMC" for the support in the development of applied research in the field of smelter slags recycling.

\section{REFERENCES}

Bondarenko, V., Kovalevska, I., \& Dychkovskyi, R.O. (2010). Preface. New Techniques and Technologies in Mining - Proceedings of the School of Underground Mining. London, United Kingdom: CRC Press, Taylor \& Francis Group. https://doi.org/10.1201/b11329

Buying Green. (2016). Luxembourg, Luxembourg: Publications Office of the European Union.

Bystritskaya, O. (2016). Vagonnyy defitsit: kak udovletvorit' potrebnost' gruzootpraviteley. Tsentr Transportnykh Strategiy. Retrieved from http://cfts.org.ua/articles/ vagonnyy defitsit kak udovletvorit potrebnost gruzootpraviteley 1107

Cheremisina, E., \& Schenk, J. (2017). No Hexavalent Chromium in Steel Slags. Stahl und Eisen, 137(8), 32-34.

Communication from the Commission to the European Parliament, the Council, the European Economic and Social Committee and the Committee of the Regions. (2008). Brussels, Belgium: Commission to the European Committee. https://doi.org/10.2779/246106

Derzhavne ahentstvo avtomobilnykh dorih Ukrainy. (2018). Interaktyvna karta remontu dorih. [online]. Available at: http://ukravtodor.gov.ua/press/news/interaktyvna karta re montu dorih vzhe pratsiuie.html

Elshkaki, A. (2013). An Analysis of Future Platinum Resources, Emissions and Waste Streams Using a System Dynamic Model of its Intentional and Non-Intentional Flows and Stocks. Resources Policy, 38(3), 241-251. https://doi.org/10.1016/j.resourpol.2013.04.002

Euroslag. (2018). Statistics 2014. [online]. Available at: http://www.euroslag.com/products/statistics/2014/

Fact Sheet. Steel Industry By-Products. (2016). Brussels, Belgium: World Steel Association.

Geiseler, J. (1996). Use of Steelworks Slag in Europe. Waste Management, 16(1-3), 59-63.

https://doi.org/10.1016/s0956-053x(96)00070-0 
Gromova, Y.A. (2012). Studying the Prospects of Innovative Development of Iron \& Steel Sector in Ukraine: Marketing Aspect. Actual Problems of Economics, 136(10), 37-45.

Karta zheleznykh dorog Donetskoy i Luganskoy oblastey. (2018). Retrieved from http://ukr-map.com.ua/243138.html

Krasnyanskiy, M.E. (2007). Utilizatsiya i rekuperatsiya otkhodov. Donetsk: Donetskiy natsional'nyy tekhnicheskiy universitet.

Kravtsiv, V., \& Kolodiichuk, I. (2016). Conceptual Foundations for the Formation of Waste Disposal Mechanism Based on the Recycling of E-Waste in Ukraine. Economic Annals-XXI, 159(5-6), 89-92.

https://doi.org/10.21003/ea.v159-19

Kuz'menko, O., Petlyovanyy, M., \& Stupnik, M. (2013). The Influence of Fine Particles of Binding Materials on the Strength Properties of Hardening Backfill. Mining of Mineral Deposits, 45-48.

https://doi.org/10.1201/b16354-10

Kuznetsov, S.N., Protopopov, E.V., Feiler, S.V., \& Temlyantsev, M.V. (2017). Injection of Iron-Bearing Concentrates Derived from Steel-Smelting Slag into the Converter Bath. Steel in Translation, 47(6), 359-362. https://doi.org/10.3103/s0967091217060067

Lundin, M., Olofsson, M., Pettersson, G., \& Zetterlund, H. (2004). Environmental and Economic Assessment of Sewage Sludge Handling Options. Resources, Conservation and Recycling, 41(4), 255-278.

https://doi.org/10.1016/j.resconrec.2003.10.006

Marín-Guirao, L., Atucha, A.M., Barba, J.L., López, E.M., \& Fernández, A.J.G. (2005). Effects of Mining Wastes on a Seagrass Ecosystem: Metal Accumulation and Bioavailabi- lity, Seagrass Dynamics and Associated Community Structure. Marine Environmental Research, 60(3), 317-337. https://doi.org/10.1016/j.marenvres.2004.11.002

Nippon Slag Association. (2018). Designation under Law on Promoting Green Purchasing. [online]. Available at: http://www.slg.jp/e/slag/green/

Okruzhayushchaya sreda Ukrainy za 2016 god. (2017). Kiev: Gosudarstvennaya sluzhba statistiki Ukrainy.

Onyshchenko, V.O., Bryzhan, I.A., \& Chevhanova, V.Y. (2014). Ecologically Oriented Development of Ukraine's Economy: Problems and Perspectives. Actual Problems of Economics, 155(5), 261-270.

Perepelitsyn, V.A., Merzlyakov, V.N., Kochetkov, V.V., Yagovtsev, A.V., \& Panov, E.V. (2017). Waste-Free Recycling of Secondary Bacor Resources. Refractories and Industrial Ceramics, 58(4), 354-356. https://doi.org/10.1007/s11148-017-0110-3

Syiemlieh, J.D. (2015). Green Growth and Coal in India. New Delhi, India: The Energy and Resources Institute.

Tripathi, L., Mishra, A.K., Dubey, A.K., Tripathi, C.B., \& Baredar, P. (2016). Renewable Energy: An Overview on its Contribution in Current Energy Scenario of India. Renewable and Sustainable Energy Reviews, (60), 226-233. https://doi.org/10.1016/j.rser.2016.01.047

Ukrtsement. (2018). Tsementni zavody Ukrainy. [online]. Available at: http://www.ukrcement.com.ua/pidpriemstva.html

Zhu, Q., Geng, Y., Fujita, T., \& Hashimoto, S. (2010). Green Supply Chain Management in Leading Manufacturers: Case Studies in Japanese Large Companies. Management Research Review, 33(4), 380-392.

https://doi.org/10.1108/01409171011030471

\section{СТАЛИЙ РОЗВИТОК ПЈДПРИМСТВ ЧОРНОЇ МЕТАЛУРГІЇ УКРАЇНИ В ОБЛАСТІ ПІДВИЩЕННЯ ЕФЕКТИВНОСТІ УТИЛІЗАЦІї ВЕЛИКОТОННАЖНИХ ПРОМИСЛОВИХ ВІДХОДІВ}

\section{О. Філоненко}

Мета. Ідентифікувати напрями сталого розвитку підприємств чорної металургії України в галузі підвищення ефективності утилізації великотоннажних промислових відходів.

Методика. Для досягнення поставленої мети в роботі використано комплексний методичний підхід, що включає аналіз даних української та зарубіжної статистики щодо накопичення й поводження з великотоннажними промисловими відходами, аналіз потенційних споживачів продукції з відходів гірничо-металургійного комплексу (ГМК) України, а також вивчення поширених політичних інструментів урегулювання питань накопичення промислових відходів у світовій практиці.

Результати. Встановлено, що першочерговий інтерес з точки зору ефективності утилізації великотоннажних промислових відходів України представляють металургійні шлаки, які є недооціненим ресурсом в економіці України. У міжнародній практиці шлаки чорної металургії використовуються в якості цінної ресурсної бази для багатьох сфер господарювання, що в більшості випадків стало можливим за рахунок впровадження політик сприяння у сфері ресурсозбереження та екології. Крім того, у даній роботі визначені основні ринкові бар'єри, що ускладнюють утилізацію металургійних шлаків в Україні, а також додаткові ринкові обмеження для металургійних комбінатів Маріуполя, що виникли в результаті військового конфлікту.

Наукова новизна. Сформульовано ряд політичних інструментів (політик сприяння у сфері ресурсозбереження та екології) національного й регіонального рівнів для створення необхідних конкурентних умов утилізації металургійних шлаків і підтримки стійкого розвитку підприємств ГМК України.

Практична значимість. Впровадження запропонованих регуляторних механізмів утилізації шлаків чорної металургії дозволить забезпечити цінною техногенною сировиною такі галузі економіки як дорожне будівництво, цементна та бетонна промисловості, сільське господарство й ряд інших галузей, а головне, гарантувати баланс стійкості на місцевому рівні та виключити необхідність відведення нових територій для розміщення промислових відходів.

Ключові слова: сталий розвиток, великотоннажні промислові відходи, металургійні шлаки, утилізаиія відходів, політичні інструменти 


\section{УСТОЙЧИВОЕ РАЗВИТИЕ ПРЕДПРИЯТИЙ ЧЕРНОЙ МЕТАЛЛУРГИИ УКРАИНЫ В ОБЛАСТИ ПОВЫШЕНИЯ ЭФФЕКТИВНОСТИ УТИЛИЗАЦИИ КРУПНОТОННАЖНЫХ ПРОМЫШЛЕННЫХ ОТХОДОВ}

\section{А. Филоненко}

Цель. Идентифицировать направления устойчивого развития предприятий черной металлургии Украины в области повышения эффективности утилизации крупнотоннажных промышленных отходов.

Методика. Для достижения поставленной цели в работе использован комплексный методический подход, включающий анализ данных украинской и зарубежной статистики по накоплению и обращению с крупнотоннажными промышленными отходами, анализ потенциальных потребителей продукции из отходов горнометаллургического комплекса (ГМК) Украины, а также изучение распространенных политических инструментов урегулирования вопросов накопления промышленных отходов в мировой практике.

Результаты. Установлено, что первоочередной интерес с точки зрения эффективности утилизации крупнотоннажных промышленных отходов Украины представляют металлургические шлаки, которые являются недооцененным ресурсом в экономике Украины. В международной практике шлаки черной металлургии используются в качестве ценной ресурсной базы для многих сфер хозяйствования, что в большинстве случаев стало возможным за счет внедрения политик благоприятствования в сфере ресурсосбережения и экологии. Кроме того, в данной работе определены основные рыночные барьеры, затрудняющие утилизацию металлургических шлаков в Украине, а также дополнительные рыночные ограничения для металлургических комбинатов Мариуполя, возникшие в результате военного конфликта.

Научная новизна. Сформулирован ряд политических инструментов (политик благоприятствования в сфере ресурсосбережения и экологии) национального и регионального уровней для создания необходимых конкурентных условий утилизации металлургических шлаков и поддержания устойчивого развития предприятий ГМК Украины.

Практическая значимость. Внедрение предложенных регуляторных механизмов утилизации шлаков черной металлургии позволит обеспечить ценным техногенным сырьем такие отрасли экономики как дорожное строительство, цементная и бетонная промышленности, сельское хозяйство и ряд других отраслей, а главное, гарантировать баланс устойчивости на местном уровне и исключить необходимость отведения новых территорий для размещения промышленных отходов.

Ключевые слова: устойчивое развитие, крупнотоннажные промышленные отходы, металлургические шлаки, утилизация отходов, политические инструменты

\section{ARTICLE INFO}

Received: 17 November 2017

Accepted: 1 March 2018

Available online: 12 March 2018

\section{ABOUT AUTHORS}

Oleksandr Filonenko, Senior Manager in Ecology of Operating Directorate of the Metinvest Holding, 1 Levchenko St, 87504, Mariupol, Ukraine. E-mail: aleksandr.filonenko@metinvestholding.com 